\title{
第二高調波発生に及ぼすパルス波形の影響*
}

\author{
大村悦二*1, 野村 和 史*2, 宮 本 勇*2
}

\section{Influence of Temporal Pulse Shape on Second Harmonic Generation}

\author{
Etsuji OHMURA*3, Kazufumi NOMURA and Isamu MIYAMOTO \\ ${ }^{*}$ Department of Manufacturing Science, Osaka University, \\ 2-1 Yamada-Oka. Suita-shi, Osáka, 565-0871 Japan
}

\begin{abstract}
Frequency conversion technique using nonlinear optical crystals in indispensable to solid-state laser applications. It is well known that the conversion efficiency is very sensitive to temperature change of crystal, which is caused by laser absorption. We have been analyzing problems of second harmonic generation ( $\mathrm{SHG}$ ) by coupling the electric field to the temperature field. In this study, temporal pulse-shape dependence of SHG was investigated theoretically, and Gaussian pulse and rectangular pulse were compared. Main conclusions obtained are as follows: (1) Both conversion efficiencies with Gaussian and rectangular pulses fluctuate with irradiation time, however the former fluctuation is slower and more gentle. ( 2 ) Pulse of output second harmonic fluctuates most remarkably at the center, where power density of incident fundamental is highest, in the Gaussian pulse. ( 3 ) As a result, pre-pulse and post-pulse are geserated before and after the main pulse. (4) Such distortion of output pulse shape becomes more remarkable as power density increases.
\end{abstract}

Key Words: Second Harmonic Generation (SHG), Nonlinear Optical Crystal, Pulse Shape, Laser Absorption, Beam Profile

\section{1. 緒}

レーザ精密微細加工は, 半導体, 電子デバイスなど の産業分野でますます期待されてきている.一般に, レーザ加工では, 複雑な加工現象が局所領域で極短時 間に生じることから，その場観察や計測，理論的解析 か灘しく, 主に，加工結果に基づく分析や経験的な立 場から研究・開発が倠められてきたといえる. そもそ もレーザ加工は光を用いるのであるから, 加工点での 物理現象や，照射条件と加工結果の関係だけでなく， 光学的な立場からの検討も含めた, 加工システムとし て総合的に捉える必要がある. 精密微細になればなる ほど, 光学的立場からの検討が重要になってくると考 えられる.

ところで, 非線形光学結晶を用いた波長変換は, 固 体レーザの精密微細加工への応用には必要不可欠であ り,すでにこれを用いた精密微細加工は多く行われて いる. しかし, 波長変換に関するこれまでの研究・開 発は, 経験的, 実験的な立場から, 変換効率の向上之 安定化に主眼が置かれてきた. そこで著者らは, 変換 効率が結晶の温度分布に強く依存すること，それが非

* 原稿受付 2003 年 8 月 1 日.

*1 正員, 大阪大学大学院工学研究科 $\left(\begin{array}{c}\mathbf{w} 5 \\ 5\end{array}\right.$ - 0871 吹田市山田 丘 2-1).

*2. 大阪大学大学院工学研究科

E-mail : ohmura (a mapse.eng.osaka-u.ac.jp
線形光学結晶のレーザ光吸収に起因することに着目し， 現象の解明と定量化を理論的に検討してきた.

まず, 第二高調波発生(SHG)について, 非線形光学 結晶のレーザ光吸収を考虑した光電場の振幅方程式を 新たに導出し, 結晶中の光波の伝播と熱伝導の連成解 析を行った ${ }^{(14)}$. 具体的には, 一軸性負結晶 $\mathrm{KH}_{2} \mathrm{PO}_{4}$ (KDP) を想定して, 空間的強度分布が一様分布 ${ }^{(1)}$ とカ ウス分布 (2)である Nd:YAG レーザを絽り返し照射した ときの SHG 変換効率を調べ, 照射条件によって変換 効率が空間的, 時間的にどの程度変動するかを定量的 に明らかにした. 同時に, 基本波としてガウシアンビ 一ムを照射すると, 出力第二高調波のビームプロファ イルがガウシアンビームにならないこと, しかも温度 制御によって変換効率を安定化させても, ビームプロ ファイルの乱れは生じることを見出した ${ }^{(3)}$.さらに, 昨今よく使用されている二軸性正結晶 $\mathrm{KTiOPO}_{4}$ (KTP)を取り上げ, KDP と比較する形で, SHG 変換 効率やビームプロファイルの空間的, 時間的変化を理 論的に解析した(4).

これまでの研究では, 入射基本波のパルスは時間的 に強度が一定の, いわゆる矩形波パルスを想定してき た. しかし, パルス幅が短くなるほどパルス波形が重 要になってくるので, 本論文では時間的にガウス分布 したパルス波形(以下, ガウシアンパルスという)を取 
り上げ，矩形波パルスと比較する形で，KTPによる第 二高調波発生における SHG 変換効率やビームプロフ アイルの空間的, 時間的変化を理論的に解析した.

\section{2. 解析方法}

図 1 に示すように, 角振動数 $\omega$ （以下, 基本波とい う)の平面波パルスが, 非線形光学結晶の入射面に垂直 に照射されるものとする. パルス幅 $\tau_{\mathrm{p}}$ を半波高全幅值 (FWHM) で定義すると, ガウシアンパルスの波形は, 時刻 $t$ の関数で

$$
y(t)=\frac{2 \sqrt{\ln 2}}{\sqrt{\pi}} \exp \left(-4 \ln 2 \frac{t^{2}}{\tau_{\mathrm{p}}^{2}}\right)
$$

と表される. したがって, 強度が空間的に一様に分布 したフルエンス $F$ のパルスのパワー密度(瞬時值)は

$$
I_{10}(t)=\frac{2 \sqrt{\ln 2} F}{\sqrt{\pi} \tau_{\mathrm{p}}} \exp \left(-4 \ln 2 \frac{t^{2}}{\tau_{\mathrm{p}}^{2}}\right)
$$

と表され，強度が空間的にもガウス分布したパルスエ ネルギー $E_{\mathrm{p}}$ のパルスのパワー密度(瞬時值)は

$$
I_{10}(r, t)=\sqrt{\frac{\ln 2}{\pi}} \frac{4 E_{\mathrm{p}}}{\pi r_{e}^{2} \tau_{\mathrm{p}}} \exp \left(-2 \frac{r^{2}}{r_{e}^{2}}-4 \ln 2 \frac{t^{2}}{\tau_{\mathrm{p}}^{2}}\right)
$$

と表される.ここで, $r_{e}$ はビーム径 $\left(1 / e^{2}\right.$ 半径)である.

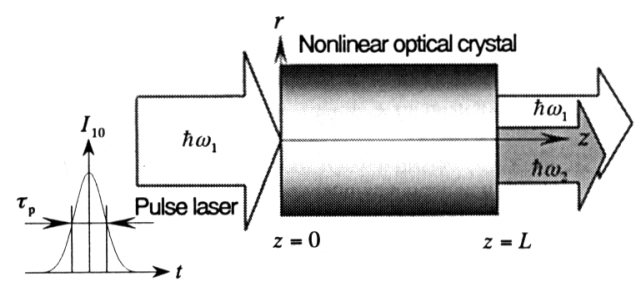

Fig. 1 Schematic of second harmonic generation

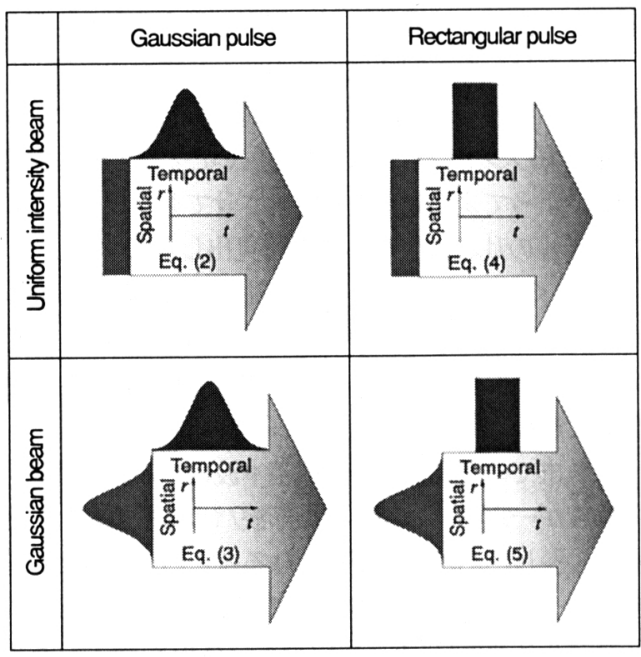

Fig. 2 Kinds of incident pulse for analysis
これより，強度が空間的に一様分布したビームを一様 強度ビーム, 強度が空間的にガウス分布したビームを ガウシアンビームと呼ぶ、これまでの研究(14)で取り扱 ってきた矩形波パルスは，矩形関数U $(x)$ を用いると， 式(2), 式(3)に対応して, それぞれ次式で与えられる.

$$
\begin{aligned}
& I_{10}(t)=\frac{F}{\tau_{\mathrm{p}}} U\left(\frac{t}{\tau_{\mathrm{p}}}\right) \\
& I_{10}(r, t)=\frac{2 E_{\mathrm{p}}}{\pi r_{e}^{2} \tau_{\mathrm{p}}} \exp \left(-2 \frac{r^{2}}{r_{e}^{2}}\right) U\left(\frac{t}{\tau_{\mathrm{p}}}\right)
\end{aligned}
$$

これら4種類のパルスを一覧にして図 2 に示す.

光波の伝播方向に $z$ 軸をとると, 非線形光学結晶内 における SHG は, 文献(1)で導出したレーザ光吸収を 考慮した基本波および第二高調波の電場の振幅 $A_{1}, A_{2}$ に関する連立微分方程式(6)により解析することがで きる.

$$
\left\{\begin{array}{l}
\frac{d A_{1}(z)}{d z}=-i d_{\mathrm{eff}} \eta_{1} \omega A_{1}(z) A_{2}(z) \exp \left[-\alpha_{2} z-i \Delta k z\right] \\
\frac{d A_{2}(z)}{d z}=-i d_{\mathrm{eff}} \eta_{2} \omega A_{1}^{2}(z) \exp \left[-\left(2 \alpha_{1}-\alpha_{2}\right) z+i \Delta k z\right]
\end{array}\right.
$$

ここで, 肩字*は複素共役, 添字 1,2 はそれぞれ基本波 と第二高調波の物理量であることを示す． $d_{\text {eff }}$ は実効 非線形定数, $2 \alpha$ は吸収係数, $\eta$ は媒質のインピーダ ンスで, $\mu, \varepsilon$ を媒質の透磁率と誘電率とするとき,

$$
\eta=\sqrt{\frac{\mu}{\varepsilon}}
$$

である. また, $k\left(=n \omega / c_{0}, n\right.$ : 屈折率, $c_{0}$ : 真空中の光 速) は波数で,

$$
\Delta k=k_{2}-2 k_{1}
$$

とおいた. KTP の届折率の主值は, 波長 $\lambda[\mu \mathrm{m}]$ と温度 $T\left[{ }^{\circ} \mathrm{C}\right]$ の関数で, 次式のように表される(5).

$$
\left\{\begin{aligned}
n_{X}^{2}(\lambda, T)= & 3.0065-5.3580 \times 10^{-7}\left(T^{2}-400\right) \\
& +\frac{0.03901+2.8330 \times 10^{-7}\left(T^{2}-400\right)}{\lambda^{2}-0.04251+7.5693 \times 10^{-7}\left(T^{2}-400\right)} \\
& -\left[0.01327-3.9820 \times 10^{-7}\left(T^{2}-400\right)\right] \lambda^{2} \\
n_{Y}^{2}(\lambda, T)= & 3.0333-2.7261 \times 10^{-7}\left(T^{2}-400\right) \\
& +\frac{0.04154+1.7896 \times 10^{-7}\left(T^{2}-400\right)}{\lambda^{2}-0.04547+5.3168 \times 10^{-7}\left(T^{2}-400\right)} \\
& -\left[0.01408-3.4988 \times 10^{-7}\left(T^{2}-400\right)\right] \lambda^{2} \\
n_{Z}^{2}(\lambda, T)= & 3.3134-1.1327 \times 10^{-7}\left(T^{2}-400\right) \\
& +\frac{0.05694+1.6730 \times 10^{-7}\left(T^{2}-400\right)}{\lambda^{2}-0.05657-0.1601 \times 10^{-7}\left(T^{2}-400\right)} \\
& -\left[0.01682+0.52833 \times 10^{-7}\left(T^{2}-400\right)\right] \lambda^{2}
\end{aligned}\right.
$$

これより, 座標主平面のうち $X Y$ 面での $293 \mathrm{~K}$ におけ る第二種位相整合の位相整合角は $24.61 \mathrm{deg}$ と求まる. これを $\phi[\mathrm{deg}]$ と書き，この角度にレーザを照射するこ 
とにすると, 基本波と第二高調波の届折率 $n_{1}, n_{2}$ は, それぞれ次式で与えられる.

$$
\left\{\begin{array}{l}
n_{1}=\frac{1}{2}\left(n_{Z}^{(\omega)}+\sqrt{\frac{\left(n_{X}^{(\omega)} n_{Y}^{(\omega)}\right)^{2}}{\left(n_{X}^{(\omega)} \cos \phi\right)^{2}+\left(n_{Y}^{(\omega)} \sin \phi\right)^{2}}}\right) \\
n_{2}=\sqrt{\frac{\left(n_{X}^{(2 \omega)} n_{Y}^{(2 \omega)}\right)^{2}}{\left(n_{X}^{(2 \omega)} \cos \phi\right)^{2}+\left(n_{Y}^{(2 \omega)} \sin \phi\right)^{2}}}
\end{array}\right.
$$

ガウシアンパルスでの $z=0$ における入射基本波の 振幅 $A_{1}(0)$ は, 式(2)または式(3)から時々刻々 $\sqrt{2 \eta I_{10}}$ で 与えられるので, これを初期値として, 式(6)を, ルン ゲクッ夕法を用いて解くことで, パルス中の結晶内に おける基本波と第二高調波の時々刻々のパワ一密度が,

$$
I_{q}(z)=\frac{1}{2 \eta_{q}}\left|A_{q}\right|^{2} \exp \left(-2 \alpha_{q} z\right), \quad q=1,2
$$

\section{により計算される.}

後述するように，熱伝導計算には有限差分法を用い ており，取り扱うパルス幅は高々 120 ps である. この ときパルス中に結晶を伝播する温度波と最も小さい格 子サイズ(約 $12 \mu \mathrm{m}$ ) との比(フーリ工数の平方根) は,

$$
\frac{\sqrt{\kappa \tau_{\mathrm{p}}}}{\Delta r}=\frac{\sqrt{\left(1.52 \times 10^{-6}\right) \times\left(120 \times 10^{-12}\right)}}{12 \times 10^{-6}} \sim 0.0011
$$

となり, パルス中の熱伝導は十分小さく無視できるこ とがわかる. ここで, $\kappa$ は熱拡散率で, 式(12)ではKTP の $293 \mathrm{~K}$ における值を用いた. そこで，パルス中は結 晶の温度変化はなく, 届折率分布は変わらないとする.

パルス中の熱伝導計算における時間刻み $\Delta t$ は, 矩形

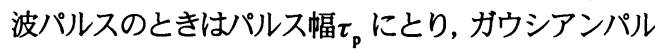
スのときは, 最大パルス長さ $4 \tau_{\mathrm{p}}$ にとる. 後者で最大 パルス長さを $4 \tau_{\mathrm{p}}$ とするのは, パルス時間を $|t| \leq 2 \tau_{\mathrm{p}}$ としたときのパルスエネルギーの相対誤差, すなわち $|t|>2 \tau_{\mathrm{p}}$ におけるパルスエネルギーと全パルスエネル ギーの比が

$$
\begin{gathered}
\frac{2}{\sqrt{\pi}} \int_{2 \tau_{\mathrm{p}}}^{\infty} \exp \left[-\left(2 \sqrt{\ln 2} \frac{t}{\tau_{\mathrm{p}}}\right)^{2}\right] d t \\
=\operatorname{erfc}(4 \sqrt{\ln 2}) \sim 2.5 \times 10^{-6}
\end{gathered}
$$

と十分小さくなるためである. したがって, 振幅 $A_{1}, A_{2}$ に関する微分方程式(6)を解くときは, 矩形波パルスに ついては入射強度が変わらないので, 1 パルスごとに 各 $r$ についてルンゲクッ夕法を 1 度適用すればよい. ガウシアンパルスのときは，パルスの中心付近の時間 間隔が細かくなるように

$t_{ \pm i}=2 \tau_{\mathrm{p}}\left[1-\frac{\ln (N+1-i)}{\ln (N+1)}\right], \quad i=0,1,2, \cdots, N$

によって分割し (具体的な数值計算では $N=10$ とし た), 各時刻でルンゲクッタ法を適用する.
パルス中の内部発熱 $w$ は, 矩形波パルスの場合は, パルス中の光強度 $I_{1}, I_{2}$ は変わらないので,

$$
w=-\frac{1}{\tau_{\mathrm{p}}} \int_{\tau_{\mathrm{p}}} \frac{d}{d z}\left(I_{1}+I_{2}\right) d t=-\frac{d}{d z}\left(I_{1}+I_{2}\right)
$$

となる. ガウシアンパルスの場合は,

$$
w=-\frac{1}{4 \tau_{\mathrm{p}}} \int_{-2 \tau_{\mathrm{p}}}^{2 \tau_{\mathrm{p}}} \frac{d}{d z}\left(I_{1}+I_{2}\right) d t=-\frac{1}{4 \tau_{\mathrm{p}}} \sum_{i=-N}^{N-1} \Delta t_{i} \frac{d}{d z}\left(I_{1 i}+I_{2 i}\right)
$$

より求まる. この内部発熱に起因する結晶内の温度分 布の時間変化は, $O-r z$ 円柱座標系における二次元非 定常熱伝導方程式

$$
\rho c \frac{\partial T}{\partial t}=\frac{1}{r} \frac{\partial}{\partial r}\left(K r \frac{\partial T}{\partial r}\right)+\frac{\partial}{\partial z}\left(K \frac{\partial T}{\partial z}\right)+w
$$

を有限差分法によって解くことで求めることができる. ここで, $\rho$ は結晶の密度, $c$ は比熱, $K$ は熱伝導率で ある. 得られた温度分布から式(10)によって屈折率分 布を求め, 再び式(6)によってつぎのパルスによる SHG 計算を行う, という手順を照射時間中繰り返す. パル スとパルスの間はレーザ吸収がないので内部発熱 $w=0$ とする.

入射端からの距離 $z$ の面における変換効率は, その 面内での第二高調波の全パワー $P^{(2 \omega)}(z)$ と入射基本波 のパワー $P^{(\omega)}(=P)$ の比で与えられる. すなわち,

$$
\frac{P^{(2 \omega)}(z)}{P^{(\omega)}}=\left(\sum_{j=1}^{m} \int_{\tau_{\mathrm{p}}} I_{j}^{(2 \omega)}(z) d t S_{j}\right) / P
$$

ここで, $I_{j}^{(2 \omega)}(z)$ は $r=r_{j}$ の距離 $z$ における第二高調波 のパワー密度, $S_{j}\left(=\pi\left(r_{j}^{2}-r_{j-1}^{2}\right)\right)$ は第 $j$ 番目の差分格 子の断面積, $m$ は $r$ 方向の差分格子の数を表す.

入射基本波にはNd:YAG レーザ(波長 $1064 \mathrm{~nm}$ )を 想定し, まず, 一様強度ビームについて, ガウシアン パルス(式(2)) と矩形波パルス(式(4))を比較する. つぎ に, カウシアンビームについても, 同様にパルス波形 (式(3), 式(5))による相違を検討する. ガウシアンビー ムの場合の解析条件を表 1 に示す。一様強度ビームの フルエンスは, ガウシアンビームの場合の平均フルエ ンス $\left(=E_{\mathrm{p}} / \pi r_{e}^{2}\right)$ と同じ $28.3 \mathrm{~mJ} / \mathrm{cm}^{2}$ とする. いずれの 場合もパルス幅 $\tau_{\mathrm{p}}$ は $60 \mathrm{ps}$ を標準条件とする. 参考ま

\begin{tabular}{l|l} 
Table 1 Analysis condition in spatially Gaussian beam irradiation \\
\hline Pulse energy $E_{\mathrm{p}}$ & $2 \mathrm{~mJ}$ \\
$1 / e^{2}$ radius $r_{e}$ & $15 \mathrm{~mm}$ \\
Pulse shape & Gaussian, rectangular \\
Pulse width $\tau_{\mathrm{p}}$ & $15, \mathrm{ps} 30 \mathrm{ps}, 60 \mathrm{ps}, 120 \mathrm{ps}$ \\
Repetition rate $f_{\mathrm{p}}$ & $500 \mathrm{~Hz}$ \\
Initial temperature $T_{0}$ & $293 \mathrm{~K}$ \\
Crystal length $L$ & $10 \mathrm{~mm}$ \\
Crystal radius $R$ & $3 \mathrm{~mm}$ \\
Number of grids in the $r$ direction $m$ & 60 \\
Number of grids in the $z$ direction $n$ & 40 \\
\hline
\end{tabular}




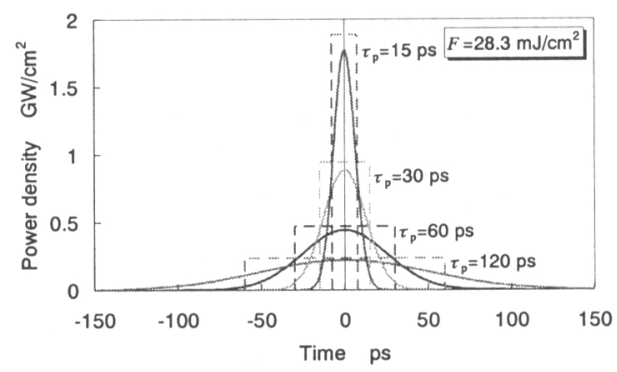

Fig.3 Temporally Gaussian and rectangular pulses used for analysis

でに，図3にパルス波形を示す．実線がガウシアンパ ルス, 破線が矩形波パルスである. いまフルエンスが 一定なので, パルス幅 $\tau_{\mathrm{p}}$ が短いほどピークパワー密度 (瞬時値)が高い.

KTP の物性値は文献(6)-(8)を参照した. 既報 ${ }^{(1-4)}$ と 同様に，一様強度ビームを照射するときの境界条件は 表面断熱とし, ガウシアンビームを照射するときは, 表面から熱放射があるものとした．そのときの外界温 度は $293 \mathrm{~K}$, 放射率は $\varepsilon=0.8$ とした. なお，境界条件 の影響は今後さらに検討していく予定である.

\section{3. 解析結果之考察}

\section{1 一様強度分布レーザ照射の場合}

図 4 は，位相整合時に 1 パルス照射したときの変換 効率の結晶内変化を, ガウシアンパルスと矩形波パル スを比較して示している. 既に知られているように, 位相整合時には結晶が長いほど変換効率が高く, パワ 一密度が高いほど変換効率の立ち上がりがよくて高効 率となる. 図 4 より, 矩形波パルスの方がガウシアン パルスより変換効率の立ち上がりがよくて，早く最大 值に達することがわかる．これは，図3からわかるよ うに, 矩形波パルスの方が, 高パワ一密度が長く持続 するためである.

繰り返し照射すると位相不整合が進むので, 変換効 率は照射時間とともに変化する. 図 5 は, パルス幅 $\tau_{\mathrm{p}}$ が $60 \mathrm{ps}$ の場合について，繰り返し照射したときの変 換効率の結晶内変化が，パルス波形によってどのよう に相違するかを示している. ガウシアンパルス(図(a)), 矩形波パルス(図(b))のいずれの場合も, 変換効率分布 は時間とともに変動している．この変動は, 位相不整 合時に生じる結晶内の SHG の逆変換に起因するもの で, パワ一密度が高いほど変動が顕著であることをす でに明らかにしている ${ }^{(1)}$. 図 5 を見るとガウシアンパ ルスの方がゆっくり変動している. 図 3 に示すように, ガウシアンパルスでは 1 パルス中に様々なパワー密度 をとり，しかも矩形波パルスに比べて低パワ一密度の

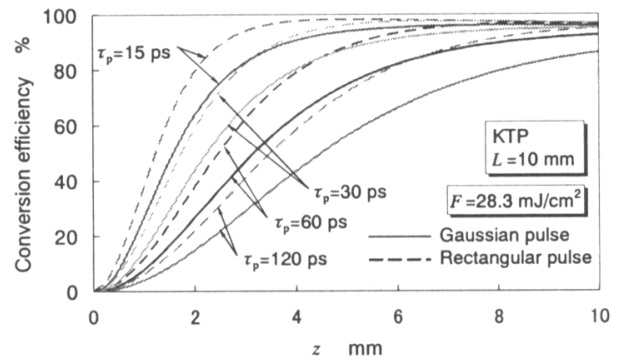

Fig. 4 Comparison of conversion efficiency distribution in the crystal by single shot under phase matching condition

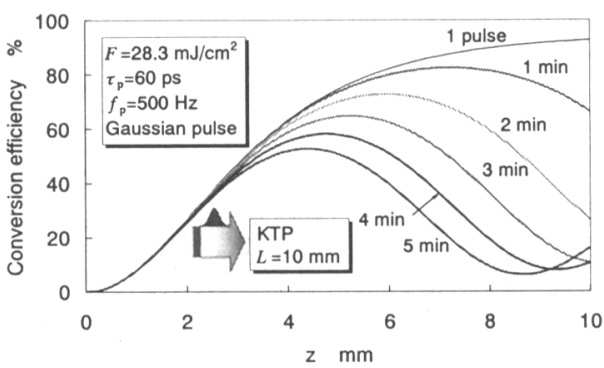

(a) Gaussian pulse

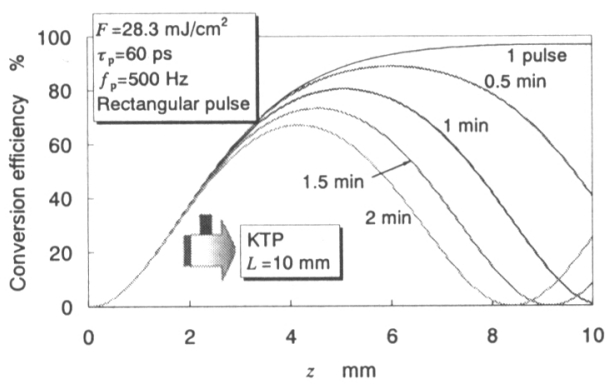

(b) rectangular pulse

Fig. 5 Comparison of time variation of conversion efficiency distribution in the crystal by repetitive irradiation $\left(\tau_{\mathrm{p}}=60 \mathrm{ps}\right)$

時間が長いことがこの原因として考えられる.このこ とを確認するため, 照射開始から $2 \mathrm{~min}$ 後の, ガウシ アンパルス中の結晶内の第二高調波のパワ一密度分布 を図 6(b)に示す. パルス中心を時刻 0 として 5 ps ごと の瞬時值を示した(図 6(a)参照). 比較のため, 同じ照射 時間における矩形波パルス照射中の第二高調波のパワ 一密度分布を破線で示した. ガウシアンパルスでは, 確かにパルス中心を離れるほど変換効率の極大值が急 激に低下し, パワ一密度の変動が緩やかになることが わかる. 図6において, 矩形波パルスの結晶内の第二 高調波パワ一密度の最大值がガウシアンパルスのそれ より小さいのは, この時刻での結晶の平均温度が, ガ ウシアンパルスのとき約 $303.3 \mathrm{~K}$ であるのに対して矩 形波パルスのときは約 $311.4 \mathrm{~K}$ と高く, それだけ位相 


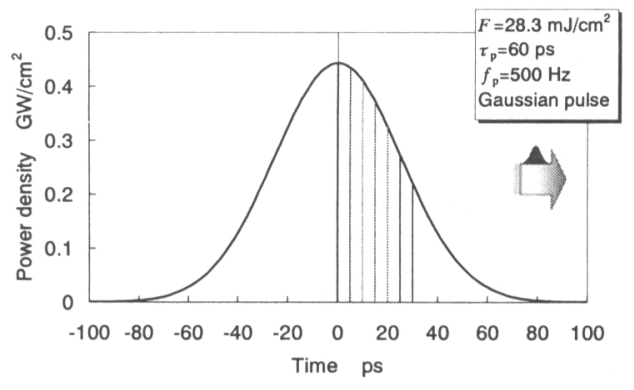

(a) incident Gaussian pulse

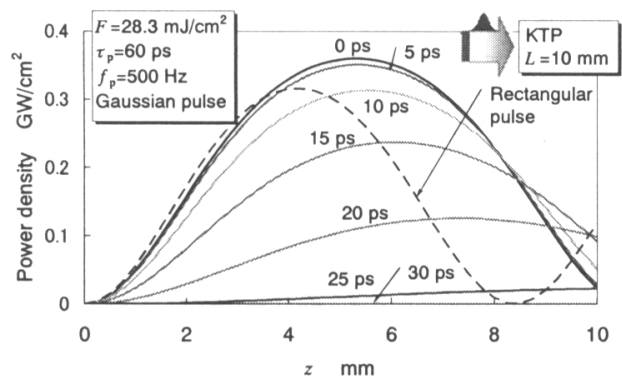

(b) second harmonic

Fig. 6 Power density distributions of incident Gaussian pulse (a) and second harmonic in the crystal at time 20 minute (b) $\left(\tau_{\mathrm{p}}=60 \mathrm{ps}\right)$

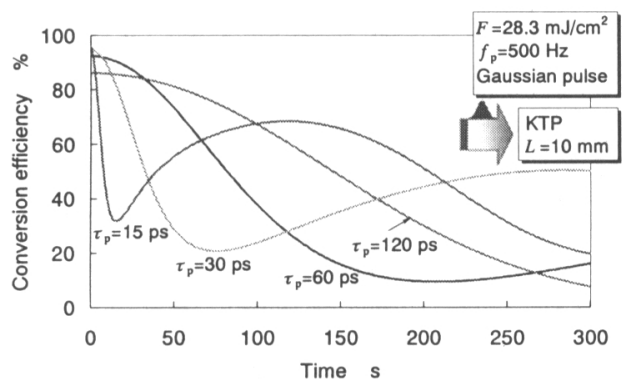

(a) Gaussian pulse

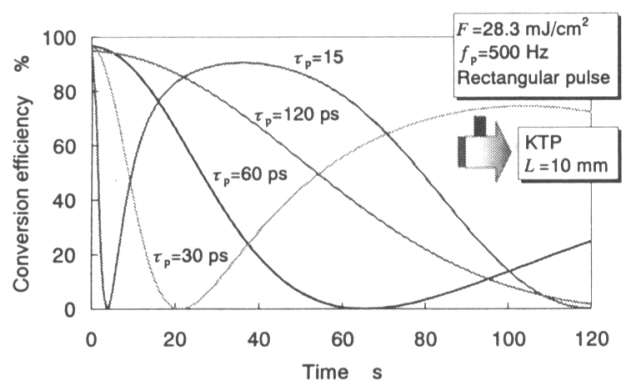

(b) rectangular pulse

Fig. 7 Comparison of time variation of conversion efficiency at the exit $\operatorname{surface}(z=L)$

不整合の度合いが大きくなっているためである。

以上のことを踏まえると, 図 7 に示すように, 出射

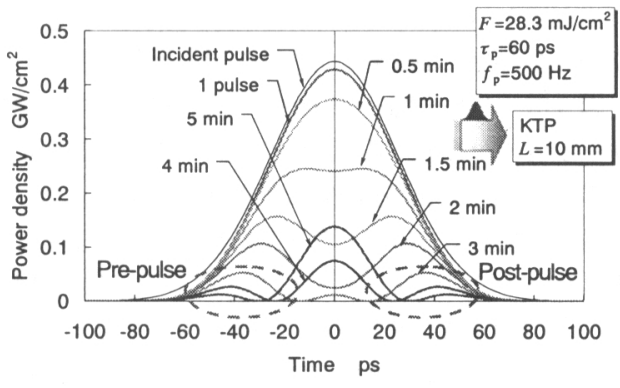

(a) Gaussian pulse

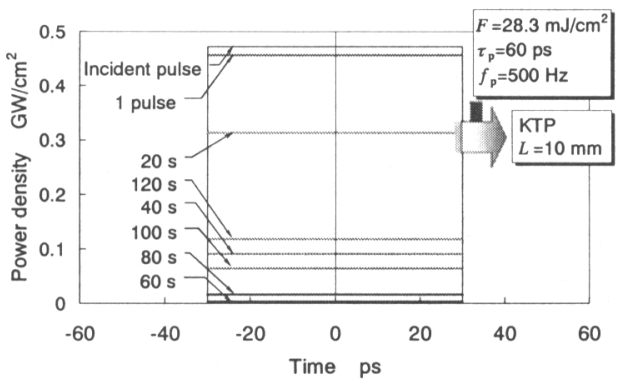

(b) rectangular pulse

Fig. 8 Comparison of time variation of output pulse shape of second harmonic $\left(\tau_{\mathrm{p}}=60 \mathrm{ps}\right)$

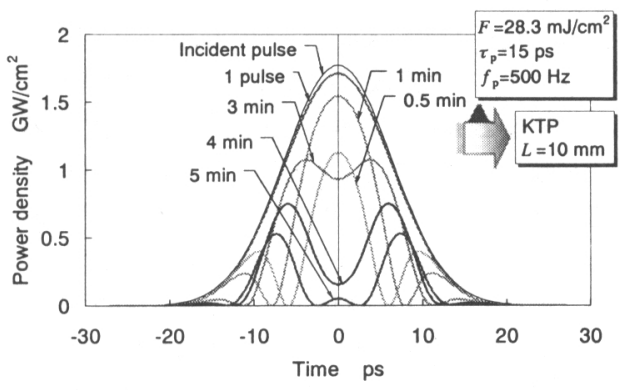

(a) $\tau_{\mathrm{p}}=15 \mathrm{ps}$

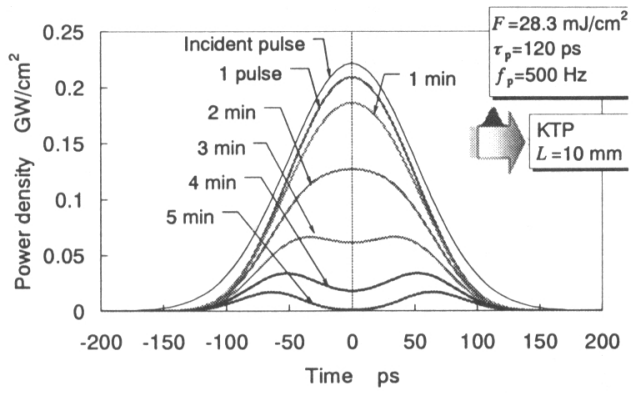

(b) $\tau_{\mathrm{p}}=120 \mathrm{ps}$

Fig. 9 Pulse width dependence of output pulse shape of second harmonic

端での変換効率が, ガウシアンパルス, 矩形波パルス のいずれの場合も時間とともに変動すること, しかし 
ガウシアンパルスの方が変動の間隔が長く, 変動もわ ずかながら穏やかであることが容易に理解される.

図 8 は, パルス幅 $\tau_{\mathrm{p}}$ が $60 \mathrm{ps}$ の場合について, 結晶 から出射される第二高調波のパルス波形の時間変化を 示す、矩形波パルスを照射したとき(図(b))は, パワー 密度は変動するものの, パルス波形は矩形のままで変 化はない，これに対して，ガウシアンパルスを照射し たとき(図(a))は, 出力パルス波形が大きくひずむ. 特 に入射パワー密度が高いパルス中心近傍で第二高調波 のパワー密度の時間変動が激しく, その結果, 図中破 線の楕円部で示すように, メインパルスの前後にプレ パルスとポストパルスが生成するという現象が生じる ことがわかる. パルス幅が異なると, 図 9 に示すよう に出力パルス波形の変動の仕方も異なる. 図 7(a)の変 換効率の時間変動に対応して, パルス幅が短いほど, すなわち入射基本波のピークパワー密度が高いほど, 出力パルス波形の変動は激しく、波形のひずみもそれ だけ大きくなることがわかる.

\section{2 ガウシアンビーム照射の場合}

つぎに, 式(3)と式(5)で表されるガウシアンビームを 表 1 の条件下で結晶に入射した場合について解析結果 を述べる.

パルス幅 $\tau_{\mathrm{p}}$ が $60 \mathrm{ps}$ と $15 \mathrm{ps}$ の場合について, ガウ シアンパルスと矩形波パルスについて変換効率の時間 変化の相違を図 10 に示す.矩形波パルスの方が初期の 変化が激しく, 特にパルス幅が短くてパワ一密度が高 いほどその傾向が強い. ガウシアンパルスは, 矩形波 パルスよりも初期の変化が緩やかである. これらの傾 向は, これまでの一様強度ビームの解析結果からも理 解される. ガウシアンパルスの変換効率はなだらかに 低下しているのに対して, 矩形波パルスの方は $5 \mathrm{~min}$ もすると比較的安定した変換効率となっている. いず れにしても，いまの境界条件では $10 \mathrm{~min}$ も照射し続け ると, 変換効率は比較的安定化することがわかる. 安

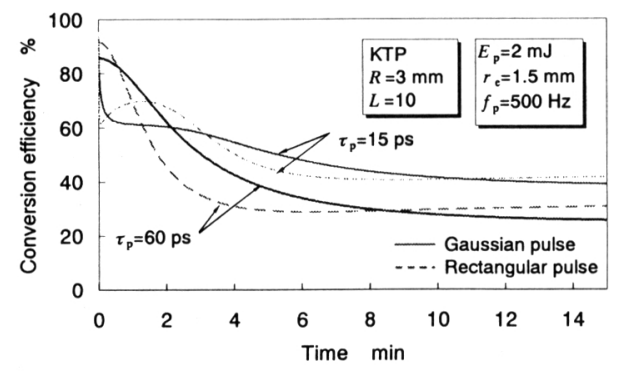

Fig. 10 Comparison of time variation of conversion efficiency between Gaussian pulse and rectangular pulse whose intensity distribution is Gaussian.
定化すると, 入射パワ一密度が高い矩形波パルスの方 が高効率となる.

図 11 は, ガウシアンパルス(式(3)) と矩形波パルス (式(5))を照射したときの出力第二高調波のビームプ ロファイルを示している. 図11(a)は, これまでの研究 (4)で得られたビームプロファイルである. すなわち, 位相整合時の 1 パルス目ではシングルモードであるが, すぐに中心部が低下し始め, 約 $1.5 \mathrm{~min}$ 後には中心の 強度分布が零にまで減少し, 完全なリングモードとな る. その後, 再び中心が盛り上がって, 10〜20 min に かけて安定化する.このときのビームプロファイルは, シングルモードのまわりに, リングが生じる. 一方,

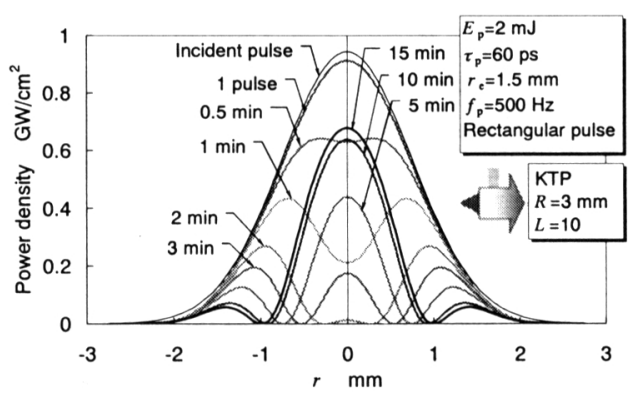

(a) rectangular pulse

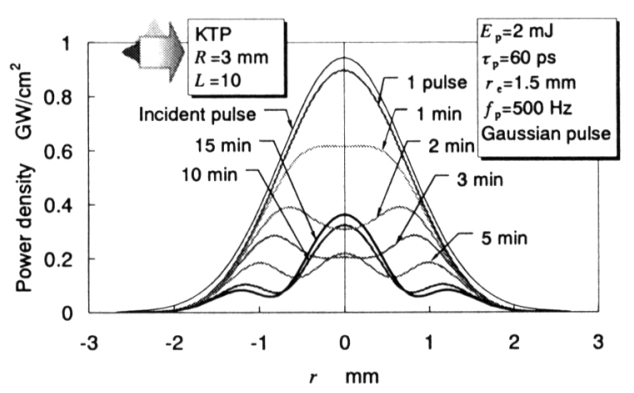

(b) Gaussian pulse

Fig. 11 Comparison of time variation of output beam profile of second harmonic $\left(\tau_{\mathrm{p}}=60 \mathrm{ps}\right)$

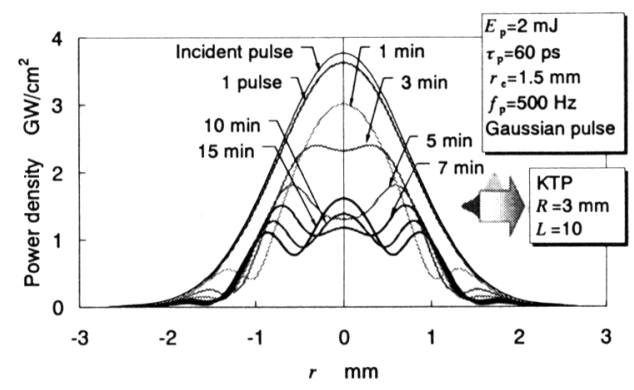

Fig. 12 Output beam profile of second harmonic with Gaussian pulse $\left(\tau_{\mathrm{p}}=15 \mathrm{ps}\right)$ 
ガウシアンパルスを照射すると, 図11(b)に示すように, 矩形波パルスと同様に出力パルス波形はひずむが，そ の変動は比較的緩やかであり, プロファイルが安定化 すると, シングルモードとリングの高低差が少なくな るとともに,その境界の谷間が浅くなることがわかる. パルス幅が $15 \mathrm{ps}$ と短くなった図12を図11(b) と比較す ると, 安定化したプロファイルは, シングルモードと リングの高低差が大きくなるとともに，その境界の谷 間も梁くなる.ここでも, パルス幅が短くパワー密度 が高いほどプロファイルのひずみが大きくなることが わかる. ただし，矩形波パルスに比べるとシングルモ ードとリングの高低差は小さくなる.

\section{4. 結言}

本研究では, 非線形光学結晶 KTP を用いた第二高調 波発生について, パルス波形を考慮して, レーザ光吸 収を考慮した光電場の複素振幅方程式と二次元熱伝導 方程式を理論的に連成解析し, 変換効率, 出力第二高 調波のパルス波形とビームプロファイルを定量的に検 討した. 得られた主な結果は以下のとおりである.

(1) ガウシアンパルスと矩形波パルスのいずれの変換 効率も, 照射時間とともに変動する. しかし, カ ウシアンパルスの変動の方がゆっくりであり, 穞 やかである.

(2) ガウシアンパルスの場合, 第二高調波の出力パル ス波形は，入射基本波のパワー密度が最も高いパ
ルス中心付近で特に顕著に変動する.

(3) その結果, メインパルスの前後にプレパルスとポ ストパルスが生成する.

(4) ガウシアンパルスの場合, 第二高調波の出カパル ス波形のひずみは, パワー密度が高いほど顕著と なる.

\section{謝辞}

本研究は, 平成 13 年度および平成 14 年度科学研究 費補助金の交付を受けていることを付記し，謝意を表 す.

$$
\text { 文献 }
$$

(1) 大村悦二, 野村和史, 宮本 勇: 非線形光学結晶によるレーザ吸 収の第二高調波発生効率への影暗，精密工学会能, 69-2, (2003), 251.

(2) 野村和史, 大村悦二, 宮本 勇: ガウシアンビームによる第二高 調波発生効率の理論解析, 精密工学会誌, 69-3,(2003), 390.

(3) 大村悦二, 野村和史, 宮本 勇: $\mathrm{KH}_{2} \mathrm{PO}_{4}$ 結晶により発生する第 二高調波のビームプロファイル解析, 機論, 70-697, C (2004), 2737-2743.

(4) 大村悦二, 野村和史, 宮本 勇: 二軸性正結晶 $\mathrm{KTiOPO}_{4}$ 結晶に より発生する第二高調波のビームプロファイル解析, 機論, 70697, C (2004), 2744-2752.

(5) B. Boulanger, J.P. Féve and Y. Guillien: Thermo-optical effect and saturation of nonlinear absorption induced by gray tracking in a 532-nm-pumped KTP optical parametric oscillator, Optics Lett, 25-7, (2000), 484.

(6) V.G. Dmitriev, G.G. Gurzadyan and D.N. Nikogosyan: Handbook of Nonlinear Optical Crystals, 3rd. ed., Springer (1999).

(7) Y. Suemune: Thermal Conductivity of Some Ferroelectric Crystals with Hydrogen Bonds, J. Phys. Soc. Japan, 22-3, (1967), 735.

(8) Z-C. Tan, G-Y. Sun, Y.J. Song L Wang J.-R. Han, Y.S. Liu, M. Wang and D.-Z Nie: An adiabatic calorimeter for heat capacity measurements of small samples: The heat capacity of nonlinear optical materials $\mathrm{KTIOPO}_{4}$ and $\mathrm{RbTOASO}_{4}$ crystals, Thermochimica Acta, 352-353, (2000), 247. 